\title{
Application of a bioenergetic growth model to larvae of the pearl oyster Pinctada margaritifera L.
}

\author{
Y. Thomas ${ }^{a, b}$, P. Garen ${ }^{a}$, S. Pouvreau ${ }^{b}{ }^{*}$ \\ a Ifremer, Laboratoire «Domestication des Huîtres Perlières», Centre de Tahiti, BP 7004, 98719 \\ Taravao, Tahiti Polynésie, French Polynesia \\ b Ifremer, Laboratoire «Physiologie et Écophysiologie des Mollusques Marins», Station d'Argenton, \\ Presqu'île du Vivier, 29840 Argenton, France

\begin{abstract}
*: Corresponding author : Stéphane Pouvreau, tel. : + 33298895332 ; fax : + 33298895777. email address : Stephane.pouvreau@ifremer.fr
\end{abstract}

\begin{abstract}
We applied, for the first time, a dynamic energy budget (DEB) growth model to the larval phase in the pearl oyster Pinctada margaritifera var. cumingii (Linné 1758) to evaluate the impact of spatio-temporal variation in the atoll lagoon environment on its capacity for development. The specific parameters of the model, which represent ingestion, temperature effect and the relationship between length and biovolume of the larvae, were determined from experiments or taken from the literature. The interpretation of the values of these parameters allowed us to identify the underlying adaptive character trait: $P$. margaritifera larvae have a good capacity to exploit low food concentrations and a narrow range of thermal tolerance restricted to hydrobiological conditions found in the tropical oligotrophic waters of its distribution zone. Growth simulations show a good fit with the observations made on reared larvae under different conditions, fed on either cultured algae or natural plankton, and with growth data from a natural cohort. Finally, a first application of the model to a pearlculture lagoon reveals the predominant effect of the vertical structure of trophic resources in determining spatial variation in larval growth.
\end{abstract}

\section{Research highlights}

We developed a DEB model for Pinctada margaritifera larvae. To our knowledge, it is the third application of a DEB model for bivalve larvae, but the first one for tropical bivalves. - This model is used to give insight into the ecology of this species. Application for aquaculture purposes is also discussed.

Keywords: Growth model, Dynamic energy budget, Larva, Pinctada margaritifera, Atoll lagoon 


\section{Introduction}

Pearl culture has a major economic and social role in French Polynesia (83 million euros in exports and about 5000 jobs). This activity is based on the production of a single species: the black-lipped pearl oyster (Pinctada margaritifera cumingii, Linné 1758). The supply of juvenile oysters for the farms is spread across thirty pearl-growing islands and atolls. This supply depends entirely on natural collection on artificial substrates, made on only about fifteen atolls. This collection is performed by trial and error and the spatio-temporal variation in yield of spat on collectors is very high (Brié 1999), meaning that local demand is not always satisfied. Combined with an overall increase in pearl culture, this demand for spat has led to significant transfers of oysters between islands, with some negative consequences: mixing of populations, which can cause a decrease in their genetic diversity (Arnaud-Haond et al., 2003), dissemination of invasive epibiota, and the risk of pathogen transmission. To increase spat collection yields in the pearl oyster industry and counter spatio-temporal variation in settlement, it appears necessary to improve our understanding of the factors that affect the success of larval development and, ultimately, settlement.

Apart from the genetically induced 'internal' parameters such as capacity for nutrition or metabolic processes (Pace et al., 2006), growth and survival of bivalve larvae depend on complex interaction between physiology, environmental conditions and food availability (Eckman 1996; Doroudi et al., 1999; Powell et al., 2002; Hofmann et al., 2004). The variability of environmental parameters and notably food availability can affect development, metamorphosis success and survival - especially through the slowing of growth, which can increase predation risks (Hofmann et al., 2004). It appears very difficult to examine larval survival and development in situ, firstly, because the dispersive nature of the pelagic larval stage necessitates a huge sampling effort (Scheltema 1986; Levin 1992) and, secondly, due to the difficulty in identifying species (Garland and Zimmer 2002). Growth models, therefore, represent an interesting alternative for studying the effect of environmental parameters on the development and survival of bivalve larvae, allowing us to identify the best periods and areas of larval settlement (Dekshenieks et al., 1993; Hofmann et al., 2004; Powell et al., 2004).

The dynamic energy budget (DEB) model has been developed and applied to adult growth in numerous bivalve species (Van Haren and Kooijman 1993; Bacher and Gangnery 2006; Casas and Bacher 2006; Pouvreau et al., 2006; van der Veer et al., 2006; Bourlès et al., 2009; Rosland et al., 2009). This generic model describes energy fluxes in an organism, from energy acquisition to its use in growth, maintenance, development and reproduction, depending on two forcing variables: temperature and food concentration. The work of RicoVilla et al., (2009) recently established a model describing growth of the Pacific oyster Crassostrea gigas (Thunberg, 1793) larval phase on the basis of DEB modelling.

In that context, the objective of our present study was, therefore, to calibrate and validate, for the first time, a DEB model for the larval phase of the pearl oyster $P$. margaritifera so as to evaluate the impact of spatio-temporal variation in the lagoon environment on larval development capacities. The model was based on that of Rico-Villa et al., (2009), using experiments to measure and define the specific parameters of $P$. margaritifera larvae, notably the ingestion function and the shape relationship between length to volume. Finally, after a $v$ alidation step, the model was applied under different food and temperature conditions recorded in the Ahe pearl farming atoll (Tuamotu archipelago), and the impact on simulated larval growth performances was evaluated. 


\section{Material and methods}

After a description of the main principles of energy acquisition and allocation, and their formulation in the DEB model, we will give the methods used to obtain values for specific parameters. Finally, we will present the larval growth data used to validate the model and the forcing variables (temperature and food) used for the application of the model.

\subsection{DEB model design for pearl oyster larvae}

The dynamic energy budget model (DEB) used in this study was developed based on DEB theory (Kooijman 2000), applied to the larval stage according to Rico-Villa et al., (2009). A full description of the processes in the model can be found for the adult stage in Pouvreau et al. (2006) and for the larval stage in the aforementioned study of Rico-Villa et al. (2009). Briefly, the DEB model distinguishes three life stages: 1) the embryo, which does not eat or reproduce; 2) the juvenile, which eats but does not reproduce; and 3 ) the adult, which eats and reproduces. The larval stage, from D-larvae onwards, corresponds to the DEB juvenile life stage. The DEB model aims to describe the growth dynamics of larvae according to different equations representing the dynamics of three state variables (Fig. 1, Table 1): the growth of structural biovolume (somatic tissues) $E_{V}$, the dynamic of energy reserves $E$, and the dynamic of energy allocated to development to reach adulthood $E_{R}$, which corresponds to the extra energy needed to achieve complexity, such as the development of the eye spot, foot or gills. Parameters of the DEB model for the larval stage in $P$. margaritifera are listed in the Table 2.

\subsection{Protocols for measuring specific parameters}

The experiments were conducted at the Ifremer centre, Tahiti. Larvae were obtained after stimulating the genitors by thermal shock (Southgate and Beer 1997). After fertilisation, the trochophore larvae were recovered and placed in 150-I rearing tanks. Tank water was renewed every two days and larvae fed daily with an algal mixture composed of cultured Isochrisis affinis galbana, Chaetoceros sp. jonquieri and Chaetoceros gracilis in a variable proportion depending on the stage of larval development.

\subsubsection{Determination of the shape coefficient $\delta_{M}$}

The value of the shape coefficient $\delta_{M}$ was determined from measurements of larval shell length and dry flesh mass, transformed into fresh mass by considering flesh water content to be $80 \%$ and converted into structural volume considering a density assumed not to be too different from $1 \mathrm{~g} \mathrm{~cm}^{-3}$. Mean length was measured by image analysis on a batch of over 30 individual larvae (IMAQ Vision Builder 6, Nat. Instrument Corporation software). Ash-free dry flesh mass, corresponding to the mass or organic material, was obtained by the difference between the total dry weight of a sample of larvae (>3000 individuals) after $24 \mathrm{~h}$ in an oven at $100{ }^{\circ} \mathrm{C}$ and the mass of mineral matter obtained after $4 \mathrm{~h}$ at $450{ }^{\circ} \mathrm{C}$. This operation was repeated at different stages of development. The shape coefficient, linking flesh volume $\left(\mathrm{cm}^{3}\right)$ and length $(\mu \mathrm{m})$, was finally adjusted considering the lower boundary of dispersion so as to include only the structural volume, without the reserves.

\subsubsection{Determination of Arrhenius parameters}

The parameters of the Arrhenius model extended to the temperature tolerance limits were taken from the data published by Doroudi et al. (1999) on the combined effects of temperature and salinity on $P$. margaritifera embryonic and larval development. The percentage embryonic development (hatching rate) and rate of growth at 6 and 15 days, obtained at optimal salinity (29 to $33.5 \mathrm{PSU}$ ) over a $r$ ange of temperature, were thus 
standardised relative to the values obtained at a reference temperature $T_{1}$ of $25^{\circ} \mathrm{C}(298 \mathrm{~K})$. The parameters of the model were then calibrated to obtain the best fit between observations and simulations.

\subsubsection{Determination of ingestion parameters $\left(\dot{J}_{X}\right)$}

Rate of ingestion was measured across a range of algal concentrations, on larvae of $3,7,11$, 15,18 and 22 days. At each of these stages, the larvae were transferred into an experimental set-up allowing the parallel testing of 5 concentrations of algae obtained by dilution of a solution of concentrated Chaetoceros $s p$. jonquieri in 1- $\mu \mathrm{m}$ filtered seawater. The mixtures thus obtained were put into $3-$ I experimental tanks maintained at $28{ }^{\circ} \mathrm{C}$, with 4 replicate tanks per concentration: 3 tanks with larvae and a fourth that served as a control, with no larvae. Algae were added to the water continuously in order to maintain a constant trophic level around the larvae, with a water flow rate corresponding to an hourly replacement of the volume of the tank. After a 2-h acclimatisation period, water samples were taken at the tank exits. Five to six samples were taken per experiment, per treatment and per tank and analysed by fluorimetry. The fluorescence was transformed to cellular concentration on the basis of a calibration curve, and to cellular biovolume $\left(\mu \mathrm{m}^{3} \mu \mathrm{l}^{-1}\right)$ by considering a mean of $25 \mu^{3}$ cell $^{-1}$ for $C$. sp. jonquieri (Robert et al., 2004). The ingestion rate $(I)$ was finally estimated as follows:

$$
I=\left[\left(\mathrm{C}_{\mathrm{C}}-\mathrm{C}_{\mathrm{L}}\right) * \mathrm{TR}\right] / V^{2 / 3}
$$

where $I$ is the daily ingestion rate expressed per unit surface $\left(\mu \mathrm{m}^{3} \mathrm{~d}^{-1} \mu \mathrm{m}^{-2}\right), C_{C}$ the algal concentration in the control tank $\left(\mu \mathrm{m}^{3} \mathrm{I}^{-1}\right), \mathrm{C}_{\mathrm{L}}$ the algal concentration in the tank with larvae $\left(\mu \mathrm{m}^{3} \mathrm{I}^{-1}\right)$, TR the rate of water renewal over $24 \mathrm{~h}\left(\mathrm{I} \mathrm{d}^{-1}\right)$ and $V$ the mean structural volume of larvae $\left(\mu \mathrm{m}^{-3}\right)$ determined after length measurement by image analysis and application of equation linking the volume to the length (Table 1).

A non-linear regression applied to the mean data for each trophic level allowed the parameters of the ingestion model, $\left\{\dot{J}_{x m}\right\}$ and $X_{k}$, to be determined. Initially expressed in cellular biovolume $\left(\mu \mathrm{m}^{3} \mu \mathrm{l}^{-1}\right)$, the coefficient of half-saturation $X_{k}$, was transformed into $\mathrm{Chl} a$ by considering the dry weight of C. sp. jonquieri as 5.4 pg cell $^{-1}$ (Robert et al. 2004) and a Chl a content corresponding to $1 \%$ of the dry weight (Brown 1991).

\subsection{Growth data for model validation}

Four types of larval growth data were used to validate the model:

1) Growth data from a larval rearing of 20 days in an open circuit with a diet of cultured algae Isochrisis affinis galbana and Chaetoceros sp. jonquieri in a 1.1 ratio.

2) Growth data from a larval rearing of 15 days conducted in situ in the lagoon of the Ahe atoll (Tuamotu archipelago) (Fig. 2), with an open circuit rearing system supplied with lagoon water (water pre-filtered to $40 \mu \mathrm{m}$ ).

3) Growth data from a larval rearing of 15 days conducted in situ in the lagoon of the Ahe atoll, performed in microcosms (net mesh $40 \mu \mathrm{m}$, volume $250 \mathrm{I}$ ) in the water of the lagoon.

4) Growth data from a cohort of 'wild' larvae from the analysis of water samples taken every two days at a station situated in the Ahe lagoon (Fig. 2). This cohort presents all the morphological and growth characteristics of a $P$. margaritifera cohort, but as species identification could not be made, we can therefore only hypothesise that this cohort really corresponds to this species. 
For each of these data sources, the concentration of $\mathrm{Chl} \mathrm{a}\left(\mu \mathrm{g} \mathrm{I}^{-1}\right)$ and temperature $\left({ }^{\circ} \mathrm{C}\right)$ were measured daily. For the simulation, the model was calibrated on parameter $X_{k}$, which is the last free-fitting parameter of our model.

\subsection{Application of the model in natural conditions}

The model was applied over a range of temperatures and in vivo Chl a concentrations ( $\mu \mathrm{g} \mathrm{I}^{-}$ ${ }^{1}$ ), measured in the Ahe lagoon during a 28 days research cruise conducted in April-May 2007. During the 28 days, vertical profiles were taken daily with a multiparameter probe at 12 stations across the lagoon (Fig 2.). For the simulations, the model applied corresponded to the version calibrated on the growth of the 'wild' cohort, the initial size of the larvae was 80 $\mu \mathrm{m}$, corresponding to D-stage larvae at 1 day, and we made the theoretical assumption that there was no dispersion. The model was used to produce the larval length reached after 28 days of simulation according to station and bathymetric level, so as to evaluate the level of variability of growth performances according to these two scales. Finally, by making the hypothesis of a normal size distribution with a standard deviation equivalent to $15 \%$ of the mean size, which is in the range of the observations made in situ and in rearing conditions, we calculated the percentage of individuals that had reached a minimum size of $230 \mu \mathrm{m}$, which is the mean size of pediveligerian larvae before settlement (Doroudi and Southgate 2003).

\subsection{Statistical analyses}

The Arrhenius temperature, $T_{A}$, corresponded to the slope (a) obtained by the linear regression $\operatorname{Ln}(\dot{k}(T))=a \times(1 / T)+b$ in the optimal thermal range, here between 24 and $27^{\circ} \mathrm{C}$ (Kooijman 2000). The temperatures at the limits, $T_{L}$ and $T_{H}$, were obtained from the range of temperatures found in Polynesian lagoons, and the Arrhenius temperatures at the limits, $T_{A L}$ and $T_{A H}$, were determined by non-linear regression based on observations.

The goodness-of-fit of the model was evaluated by linear regression between the observations $(X)$ and the simulations $(Y)$, which was tested against the model $Y=X$ at an alpha error threshold of $5 \%$. The $\mathrm{R}^{2}$ coefficient of determination allowed us to evaluate how much of the variance was explained by the model.

\section{Results}

\subsection{Estimation of parameters specific to the model}

The value of the shape coefficient, $\delta_{\mathrm{M}}$, calculated from the allometric relationship between length and flesh volume (Fig. 3) was 0.64 for a P. margaritifera larva $(n=24)$. At the D-stage, therefore, which corresponds to the very first stage of larval development, the flesh mass was $134 \mathrm{ng}$ for a length of $80 \mu \mathrm{m}$. This mass increased progressively to reach close to 2100 $\mathrm{ng}$ for a length of $200 \mu \mathrm{m}$ in the first pediveligerian larvae.

The parameters of the Arrhenius law extended to the limits of temperature tolerance were derived from data taken from Doroudi et al. (1999) (Fig. 4). The Arrhenius temperature $\left(T_{A}\right)$ representing the growth rate of the physiological process in the optimal temperature range is $14000 \mathrm{~K}$. The temperatures at the lower $\left(T_{L}\right)$ and upper $\left(T_{H}\right)$ limits are 294 and $303 \mathrm{~K}$, respectively. The Arrhenius temperatures beyond the range of optimal temperature, obtained by non-linear regression, are $87600 \mathrm{~K}$ for the lower limit $\left(T_{A L}\right)$ and $62200 \mathrm{~K}$ for the upper limit $\left(T_{A H}\right)$. The thermal optimum is around $28{ }^{\circ} \mathrm{C}$. The linear regression $Y=X$ between the model and the observations gives a coefficient of determination of $R^{2}=0.9(p<0.0001)$. 
The relationship between ingestion rate of larvae and the concentration of $C$. sp jonquieri (Fig. 5) allows us to obtain a maximum surface-specific ingestion rate, $\left\{\dot{J}_{X m}\right\}$, of $37 \mu \mathrm{m}^{3} \mu \mathrm{m}^{-}$ ${ }^{2} \mathrm{~d}^{-1}$ at $25^{\circ} \mathrm{C}$ or the equivalent of $1.7 \times 10^{-7} \mathrm{~J} \mathrm{um}^{-2} \mathrm{~d}^{-1}$, using a conversion coefficient for food energy content $\mu_{X}$, of $4.5 \times 10^{-9} \mathrm{~J} \mathrm{\mu m}^{-3}$ (Table 2). The half-saturation of the type-II Holling model, $X_{K}$, which corresponds to the food concentration at which half the maximum ingestion

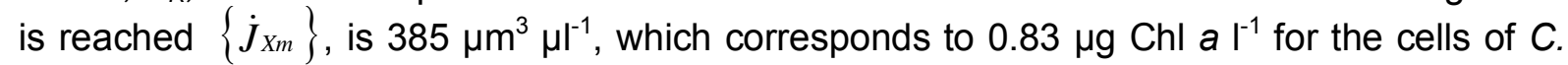
sp. jonquieri.

\subsection{Model validation}

The model was validated on the growth data from the four different conditions described. The temperature profiles and $\mathrm{Chl}$ a concentration used as forcing variables for the simulations are presented in Fig. 6. In the case of larval rearing with a supply of cultured algae, the mean temperature was $27.7 \pm 0.3{ }^{\circ} \mathrm{C}$ with a mean food concentration of $2.7 \pm 0.9 \mu \mathrm{g} \mathrm{Chl} \mathrm{a}{ }^{-1}$. For the rearing in situ, the mean temperature was $26.6 \pm 0.4{ }^{\circ} \mathrm{C}$ in both cases, and the food

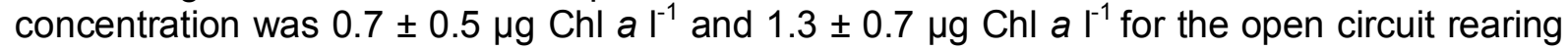
and mesocosm, respectively. Finally, in the case of the cohort obtained from water sampling in the lagoon, the mean temperature was $29.2 \pm 0.1^{\circ} \mathrm{C}$ and the food concentration $0.5 \pm 0.2$

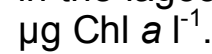

The result of the comparison between simulations and observations is presented in Fig. 7. In the case of larval rearing with cultured algae, the value of the half-saturation coefficient, $X_{k}$,

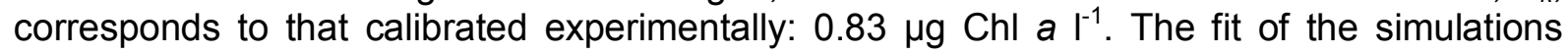
seems to be correct despite a slight overestimation at the beginning of growth $\left(Y=X ; R^{2}=\right.$ $0.96, p<0.0001)$. For the in situ rearing, the half-saturation parameter was calibrated at 0.3

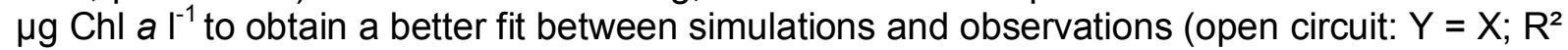
$=0.93 ; p<0.0001$, mesocosm: $\left.Y=X ; R^{2}=0.95 ; p<0.0001\right)$. In both cases, the inflection of growth observed after 5 days of rearing is correctly reproduced, as is the increase in growth at the end of rearing, which appears considerably stronger for the larvae reared in the mesocosm. In the case of the cohort identified in situ, the $X_{k}$ parameter was set at $0.15 \mu \mathrm{g}$

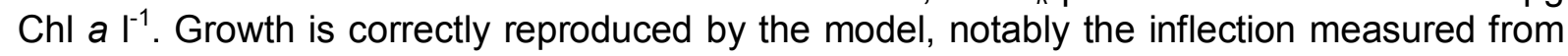
day 10 to day $20\left(Y=X ; R^{2}=0.99 ; p<0.0001\right)$.

\subsection{Application of the model}

The forcing data ( $\mathrm{Chl}$ a and temperature) are presented in Fig. 8. The concentrations of $\mathrm{Chl}$ a

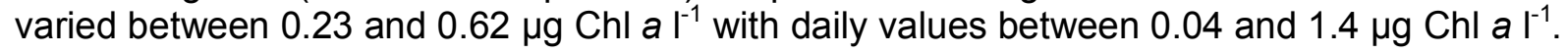
Variation along the bathymetric gradient appeared to be greater than variations at the scale of the lagoon. An increasing concentration gradient was observed between the surface and bottom. The strongest concentrations were measured in the west of the lagoon at station 01 and in the extreme east. The central part of the lagoon appeared poorer, notably near the pass (stations 03 and 04). Mean temperatures varied between 29.2 and $29.4{ }^{\circ} \mathrm{C}$. Although relatively weak, temperature variation appeared greater between the different areas of the lagoon than according to depth, the water column being relatively homogeneous.

The profile of larval lengths, obtained after 28 days of simulation, is presented in Fig. 9 . The final size varied between 144 and $189 \mu \mathrm{m}$. A critical period appears between days 10 and 20, during which growth stops in certain strata.

The general appearance obtained according to the double spatial gradient is similar to that observed for Chl a, with variation along the bathymetric gradient superior to that seen at the scale of the lagoon, and an increasing size gradient between the surface and the bottom. The maximum sizes were observed towards the bottom at station 01 and follow the $\mathrm{Chl} a$ 
gradients already mentioned. The spacing of isolines in the eastern part of the lagoon should be noted, as this seems to indicate low variability on the bathymetric gradient in this area. The lowest growth performances are observed on the surface at the stations close to the pass (stations 03 and 04), where the $\mathrm{Chl}$ a concentrations are the lowest.

The percentage of larvae reaching a minimum size of $230 \mu \mathrm{m}$ is presented in Fig. 10. After 10 days of development, $0.01 \%$ of larvae had reached a size of $230 \mu \mathrm{m}$, after 20 days 0.73 $\%$ had reached this size, and by 29 days the percentage was between 0 and $16 \%$ with a mean of $3 \%$. In the same way as with $\mathrm{Chl}$ a and growth performances, the maximum was reached in the deep layers of the western sector and the minimum at the surface opposite the pass (stations 03 and 04).

\section{Discussion}

In this study, we demonstrated the capacity of the DEB model to correctly reproduce larval growth of the pearl oyster $P$. margaritifera under different conditions of temperature and food. An advantage of the DEB model is its generic nature. Physiological processes and energy allocations are described in a single manner for all species and all stages of development through a set of ten primary parameters. The only difference between species is in the value of these parameters (Kooijman 2000). The DEB model has been applied to many species of bivalve (Vanharen and Kooijman 1993; Bacher and Gangnery 2006; Casas and Bacher 2006; Pouvreau et al., 2006; Bourlès et al., 2009; Rico-Villa et al., 2009; Rosland et al., 2009) and fish (van der Veer et al., 2001; Bodiguel et al., 2009; Pecquerie et al., 2009). To adapt the DEB model to the larval stage of pearl oyster $P$. margaritifera, only four primary parameters were modified compared with the previous $C$. gigas larval model of Rico-Villa et al. (2009): the Arrhenius temperature, the maximum surface-specific ingestion rate, the halfsaturation coefficient of the ingestion model and the assimilation efficiency. We established that the shape parameter which defines the relation between length and volume for pearl oyster larvae is the same as that of Pacific oyster C. gigas, $\delta_{M}=0.64$, showing that morphological development is identical in the larvae of these two species. This parameter is, however, different between larvae and adults: the value for adult $P$. margaritifera is estimated at 0.24 (Pouvreau et al., 2009).

The Arrhenius temperature, $T_{A}$, adjusted to the temperature tolerance range of $P$. margaritifera larvae is $14000 \mathrm{~K}$. This value differs from those described for the larvae of Macoma balthica and Crassostrea gigas, which were $7596 \mathrm{~K}$ and $11000 \mathrm{~K}$, respectively (Bos et al., 2006; Rico-Villa et al., 2009). M. balthica and C. gigas are species from cold to temperate environments and thus have a broader range of thermal tolerance and a lower $T_{A}$ than $P$. margaritifera, which is a tropical stenotherm. The hypotheses proposed by Kooijman (2000) on the inter-specific variability of $T_{A}$ are therefore verified in the context of our study.

In parallel, we measured a maximum surface-specific ingestion of $37 \mu \mathrm{m}^{3} \mathrm{~d}^{-1} \mu \mathrm{m}^{-2}$ comparable with the values described by Doroudi et al. (2003), who established a maximum of $38 \mu \mathrm{m}^{3} \mathrm{~d}^{-1} \mu \mathrm{m}^{-2}$ with a ration of $670 \mu \mathrm{m}^{3} \mu \mathrm{l}^{-1}$ of the alga Pavlova salina. These values are nevertheless considerably lower than those described for $C$. gigas larvae, found to be 137 $\mu \mathrm{m}^{3} \mathrm{~d}^{-1} \mu \mathrm{m}^{-2}$ at $25^{\circ} \mathrm{C}$ (Rico-Villa et al., 2009), but this specie inhabits estuaries which are known to be rich in phytoplankton and particulate organic matter in spring and summer. On the other hand, larvae of $P$. margaritifera are capable of exploiting ingested energy more efficiently. For pearl oyster larvae, the assimilation rate $\left(\kappa_{A}\right)$ was maintained at 0.75 as described for numerous species of bivalves (van der Veer et al., 2006). Additionally, it was noted that a type-II functional response was better adapted for pearl oyster larvae than a type-III response. The model describes no inflection for very low food concentrations, unlike the functional response of a type-III model (Baldwin and Newell 1995). Trophic resources are thus rapidly exploited by the larvae, even when food is at low concentration. The larvae of $P$. 
margaritifera have a half-saturation coefficient, $X_{k}$, of $385 \mu \mathrm{m}^{3} \mu \mathrm{l}^{-1}$, which is clearly lower than the $600 \mu^{3} \mu^{-1}$ measured in the larvae of $C$. gigas by Rico-Villa et al. (2009). Larvae of $P$. margaritifera therefore reach their maximum ingestion quicker, allowing them to better exploit low food concentrations found in the oligotrophic waters of tropical lagoons. This characteristic could be related to the high filtration capacities measured in $P$. margaritifera adults (Pouvreau et al., 1999).

Nevertheless, the adjustment of the simulations to the observation required a modification of the half saturation coefficient, $X_{k}$, depending on the type of growing environment. For the larval rearing done with cultured algae, the half-saturation measured on the cultured algae gave a good fit. For the in situ rearing, however, and the 'wild' cohort, the half-saturation coefficient had to be reduced. This type of adjustment between feeding on cultured algae and in the natural environment has already been described, notably for $C$. gigas (Bacher and Gangnery 2006; Pouvreau et al., 2006; Bourlès et al., 2009). This modification is presumably due to the quality of trophic resources. In larval rearing, the food supply is generally composed of a mono- or bi-specific diet, while there is much greater food species richness in the natural environment. Also, we used chlorophyll a (Chl a) as a des criptor of food resources although the $\mathrm{Chl}$ a composition of phytoplanktonic cells can vary between species and with environmental conditions, as can the ratio of carbon/Chl a, which is an indicator of the energy content of cells (Pridmore and Hewitt 1984; Cloern et al., 1995). Larvae are also susceptible to exploit resources other than autotrophic plankton, such as bacteria (Tomaru et al., 2000), heterotrophic plankton and dissolved matter (Olson and Olson 1989; Baldwin and Newell 1995). Nevertheless, the model seems capable of reproducing growth correctly with $\mathrm{Chl}$ a forcing, notably in variable conditions such as those observed in the in situ trials. Other than the possibility that other food sources contribute to larval growth, presenting a c ovariance with the phytoplankton, $\mathrm{Chl}$ a appears to be a good descriptor of the food of $P$. margaritifera larvae in the natural environment.

The application of the model showed us that growth performance varied principally according to bathymetric level on the scale of the lagoon as a whole. This variability appeared directly linked to the presence of a strong gradient of food concentration with depth, while temperature showed only weak absolute variations. Additionally, daily variations in food concentration appear to play an important role, with certain sectors showing a complete halt in growth during a period of nearly 10 days. At the scale of the lagoon, only the western part (stations 01 and 02) was distinguished by clearly higher growth performances than the rest of the atoll. In contrast, the sector directly under the influence of the pass (stations 03 and 04) is subjected to a dilution effect from poorer oceanic waters, causing a decrease in concentration of trophic resources available for larvae. The sizes reached at the end of 29 days of simulated growth indicate that all of the sectors and bathymetric levels showed at least some growth. If one considers the mean size for larvae ready to settle to be $230 \mu \mathrm{m}$, however, our simulations indicate that this cannot be reached within 29 days. The time for larval development before settlement is therefore longer than the 16-21 days achieved under larval culture conditions (Doroudi and Southgate 2003). Our model is one based on means, however, which do not take into account inter-individual variability. Genetically-defined internal parameters, such as the capacity for nutrition or metabolic processes (Pace et al., 2006), are likely to considerably modify the growth capacity of an organism. In their application of the DEB model to adult $C$. gigas, Bacher \& Gangnery (2006) showed that a standard deviation of $24 \%$ around the half-saturation value $\left(X_{k}\right)$ allowed a correct reproduction of the observed dispersion of sizes, and that $10 \%$ variation in $X_{k}$ would make the final size vary by $10 \%$.

In our case, the application of a size dispersion of $15 \%$ of the mean size allowed us to identify a percentage of pediveliger larvae between 0 and $16 \%$ after 27 days of simulation. In this case, the first pediveliger larvae are observed from 15 days, at the very low proportion of $0.01 \%$. This percentage reached a mean of $3 \%$ at the end of 29 days development. 
However, the dispersion of sizes in natural cohorts is unknown and thus still needs to be determined. Additionally, these simulations represent a static view of the lagoon that does not take into account the capacities of larvae to move around, either vertically or horizontally. In sum, it is difficult to draw conclusions about variability in recruitment at this stage without taking into account larval movement.

In conclusion, our study has further confirmed the generic character of the DEB model. We successfully adapted the model initially developed for $C$. gigas larvae by Rico-Villa et al. (2009), by modifying only four of the primary parameters presented as specific in the theory. We were able to extract the adaptive character underlying this modification of the parameters: $P$. margaritifera larvae show a greater capacity to exploit, as adults do, low food concentrations than $C$. gigas larvae and a restricted thermal tolerance range corresponding to the hydrobiological conditions found in the oligotrophic tropical waters that characterise the distribution area of $P$. margaritifera.

Following on from the 'scope for growth' model built for the adult phase of black-lipped pearl oyster by Pouvreau et al (2000), our model is the first adapting and applying DEB theory to the larval stage in the species. A first application of the model allowed us to assess the environmental influence on the growth capacities of $P$. margaritifera larvae in a pearl-farming lagoon. A predominant effect of the vertical structure of trophic resources was revealed on the spatial determinism of larval growth. Coupling between this model and one of larval transport appears to be an interesting prospect for predicting the traits of larval life in the lagoon and, ultimately, forecasting settlement of the black-lipped pearl oyster.

\section{Acknowledgements}

This study was co-funded by the French institute for the exploitation of the sea (Ifremer) and the government of French Polynesia (research delegation) and the $9^{\text {th }}$ European Development Fund (EDF). The authors thank the Ifremer and EDF teams who participated in the experiments conducted at Ifremer Tahiti and on Ahe atoll and thank $\mathrm{H}$. McCombie for her helpful comments and English revision.

\section{References}

Arnaud-Haond, S., Vonau, V., Bonhomme, F., Boudry, P., Prou, J., Seaman, T., Veyret, M., Goyard, E. 2003. Spat collection of the pearl oyster (Pinctada margaritifera cumingii) in French Polynesia: an evaluation of the potential impact on genetic variability of wild and farmed populations after 20 years of commercial exploitation. Aquaculture 219:181-192.

Bacher, C., Gangnery, A. 2006. Use of dynamic energy budget and individual based models to simulate the dynamics of cultivated oyster populations. J. Sea Res. 56:140-155.

Baldwin, B. S., Newell, R. I. E. 1995. Feeding rate response of oyster larvae (Crassostrea virginica) to seston quantity and composition. J Exp. Mar. Biol. Ecol. 189:77-91.

Bodiguel, X., Maury, O., Mellon-Duval, C., Roupsard, F., Le Guellec, A.-M., Loizeau, V. 2009. A dynamic and mechanistic model of PCB bioaccumulation in the European hake (Merluccius merluccius). J. Sea Res. 62:124-134.

Bos, O. G., Hendriks, I. E., Strasser, M., Dolmer, P., Kamermans, P. 2006. Estimation of food limitation of bivalve larvae in coastal waters of north-western Europe. J. Sea Res. 55:191-206.

Bourlès, Y., Alunno-Bruscia, M., Pouvreau, S., Tollu, G., L eguay, D., Arnaud, C., Goulletquer, P., Kooijman, S. A. L. M. 2009. Modelling growth and reproduction of the Pacific oyster Crassostrea gigas: Advances in the oyster-DEB model through application to a coastal pond. J. Sea Res. 62:62-71. 
Brié, C. 1999. Etude experimentale du collectage de naissain de Pinctada margaritifera (Linné, 1758) à T akapoto, atoll des Tuamotu; en Polynesie Française. Mémoire EPHE:87p.

Casas, S., Bacher, C. 2006. Modelling trace metal $(\mathrm{Hg}$ and $\mathrm{Pb})$ bioaccumulation in the Mediterranean mussel, Mytilus galloprovincialis, applied to environmental monitoring. J. Sea Res. 56:168-181.

Cloern, J. E., Grenz, C., Vidergar-Lucas, L. 1995. An empirical model of the phytoplankton chlorophyll: carbon ration - the conversion factor between productivity and growth rate. Limnol. Oceanogr. 40:1313-1321.

Dekshenieks, M. M., Hofmann, E. E., Powell, E. N. 1993. Environmental-effects on the growth and development of eastern oyster, Crassostrea virginica (Gmelin, 1791), larvae A modeling study. J. Shellfish Res. 12:241-254.

Doroudi, M. S., Southgate, P. C. 2003. Embryonic and larval development of Pinctada margaritifera (Linnaeus, 1758). Molluscan Res. 23:101-107.

Doroudi, M. S., Southgate, P. C., Lucas, J. S. 2003. Variation in clearance and ingestion rates by larvae of the black-lip pearl oyster (Pinctada margaritifera, L.) feeding on various microalgae. Aquac. Nut. 9:11-16.

Doroudi, M. S., Southgate, P. C., Mayer, R. J. 1999. The combined effects of temperature and salinity on embryos and larvae of the black-lip pearl oyster, Pinctada margaritifera (L.). Aquac. Res. 30:271-277.

Eckman, J. E. 1996. Closing the larval loop: Linking larval ecology to the population dynamics of marine benthic invertebrates. J Exp. Mar. Biol. Ecol. 200:207-237.

Garland, E. D., Zimmer, C. A. 2002. Techniques for the identification of bivalve larvae. Mar. Ecol. Prog. Ser. 225:299-310.

Hofmann, E. E., Powell, E. N., Bochenek, E. A., Klinck, J. A. 2004. A modelling study of the influence of environment and food supply on survival of Crassostrea gigas larvae. J. Mar. Sci. 61:596-616.

Kooijman, S. A. L. M. 2000. Dynamic Energy and Mass Budget in biological systems. Cambridge University press:424 pp.

Levin, S. A. 1992. The problem of pattern and scale in ecology. Ecology 73:1943-1967.

Olson, R. R., Olson, M. H. 1989. Food limitation of planktonic marine invertebrate larvae does it control recruitment success? Ann. Rev. Ecol. Syst. 20:225-247.

Pace, D. A., Marsh, A. G., Leong, P. K., Green, A. J., Hedgecock, D., Manahan, D. T. 2006. Physiological bases of genetically determined variation in growth of marine invertebrate larvae: A study of growth heterosis in the bivalve Crassostrea gigas. J Exp. Mar. Biol. Ecol. 335:188-209.

Pecquerie, L., Petitgas, P., Kooijman, S. A. L. M. 2009. Modeling fish growth and reproduction in the context of the Dynamic Energy Budget theory to predict environmental impact on anchovy spawning duration. J Sea Res. In Press, Corrected Proof.

Pouvreau, S., Bacher, C., Heral, M. 2000. Ecophysiological model of growth and reproduction of the black pearl oyster, Pinctada margaritifera: potential applications for pearl farming in French Polynesia. Aquaculture 186:117-144.

Pouvreau, S., Bourlès, Y., Lefebvre, S., Gangnery, A., Alunno-Bruscia, M. 2006. Application of a dynamic energy budget model to the Pacific oyster, Crassostrea gigas, reared under various environmental conditions. J. Sea Res. 56:156-167.

Pouvreau, S., Fournier, J., Soyez, C., Le Moullac, G. 2009. Modélisation de la croissance et de la reproduction de l'huître perlière. Rapport de mission - FED Polynésie AP2:12 pp.

Pouvreau, S., Jonquieres, G., Buestel, D. 1999. Filtration by the pearl oyster, Pinctada margaritifera, under conditions of low seston load and small particle size in a tropical lagoon habitat. Aquaculture 176:295-314.

Powell, E. N., Bochenek, E. A., Klinck, J. M., Hofmann, E. E. 2002. Influence of food quality and quantity on the growth and development of Crassostrea gigas larvae: a modeling approach. Aquaculture 210:89-117. 
Powell, E. N., Bochenek, E. A., Klinck, J. M., Hofmann, E. E. 2004. Influence of short-term variations in food on survival of Crassostrea gigas larvae: A modeling study. J. Mar. Res. 62:117-152.

Pridmore, R. D., Hewitt, J. E. 1984. Chlorophyll a as an indicator of phytoplankton cell volum in 12 lakes, North-Island, New-Zeland. New Zeal. J. Bot. 22:295-301.

Rico-Villa, B., Bernard, I., Robert, R., Pouvreau, S. 2009. A dynamic energy budget (DEB) growth model for Pacific oyster larvae, Crassostrea gigas. Aquaculture in press.

Robert, R., Chrétiennot-Dinet, M. J., Kaas, R., Martin-Jézéquel, V., Moal, J., Le Coz, J. R., Nicolas, J. L., Bernard, E., Connan, J. P., Le Déan, L., Le Gourrierec, G., L eroy, B., Quéré, C. 2004. Amélioration des productions phytoplanctoniques en écloserie de mollusques: caractérisation des microalgues fourrage. Rapport interne, Ifremer:84 pp.

Rosland, R., Strand, Ø., A lunno-Bruscia, M., Bacher, C., Strohmeier, T. 2009. Applying Dynamic Energy Budget (DEB) theory to simulate growth and bio-energetics of blue mussels under low seston conditions. J Sea Res. 62:49-61.

Scheltema, R. S. 1986. On dispersal and planktonic larvae of benthic invertebrates - an eclectic overview and summary of problems. Bull. Mar. Sci. 39:290-322.

Southgate, P. C., Beer, A. C. 1997. Hatchery and early nursery culture of the blacklip pearl oyster (Pinctada margaritifera L.). J. Shellfish Res. 16:561-567.

Tomaru, Y., Kawabata, Z., Nakano, S. 2000. Consumption of picoplankton by the bivalve larvae of Japanese pearl oyster Pinctada fucata martensii. Mar. Ecol. Prog. Ser. 192:195202.

van der Veer, H. W., Cardoso, J., van der Meer, J. 2006. The estimation of DEB parameters for various Northeast Atlantic bivalve species. J. Sea Res. 56:107-124.

van der Veer, H. W., Kooijman, S., van der Meer, J. 2001. Intra- and interspecies comparison of energy flow in North Atlantic flatfish species by means of dynamic energy budgets. J. Sea Res. 45:303-320.

Van Haren, R. J. F., Kooijman, S. 1993. Application of dynamic energy budget model to Mytilus edulis (L.). Neth. J Sea Res. 31:119-133. 


\section{Figure captions}

Fig. 1 Schematic representation of energy allocation according to DEB theory for larvae of $P$. margaritifera. State variables are shown on a rectangular grey background and forcing variables are circled.

Fig. 2 Left: geographic position of the Ahe atoll. Right: location of the in situ rearing area ( $\square$, the sampling station where the 'wild' cohort was collected (01), and the 12 sampling stations for the application of the model (01-12).

Fig. 3 Relation between shell length $(\mu \mathrm{m})$ and wet flesh mass $(\mathrm{ng})$ of $P$. margaritifera larvae. The line corresponds to the model fitted on the lower envelope of dispersion, allowing only the structural part of the flesh mass to be integrated, without the reserves.

Fig. 4 Effect of temperature on rate of embryonic development $(\Delta)$, the growth rate at 6 days of rearing $(O)$ and at 15 days of rearing $(\square)$. Data taken from Doroudi et al. (1999). The line corresponds to a mean model fitted from the equation describing the effect of the temperture in Table $2\left(Y=X ; R^{2}=0.9, p<0.0001\right)$.

Fig. 5 Evolution of ingestion rate in larvae of $P$. margaritifera depending on the concentration of the alga Chaetoceros sp jonquieri. The line represents the model fitted, with $\left\{\dot{J}_{X m}\right\}=37 \mu \mathrm{m}^{3} \mathrm{~d}^{-1} \mu \mathrm{m}^{-2}$ and $X_{k}=385 \mu \mathrm{m}^{3} \mu \mathrm{l}^{-1}\left(\mathrm{Y}=\mathrm{X} ; \mathrm{R}^{2}=0.9 ; \mathrm{p}<0.0001\right)$.

Fig. 6 Evolution of forcing variables (full line: $\mathrm{Chl} a$; dotted line: temperature) used to validate the model: (a) rearing in an open circuit with cultured algae as a food supply, (b) rearing in an open circuit with water from the Ahe lagoon, (c) rearing in a mesocosm in the Ahe lagoon, (d) measurements made in situ, in the Ahe lagoon.

Fig. 7 Comparison of observed (points \pm standard deviation) and simulated (line) larval growth of $P$. margaritifera: (a) rearing in an open circuit with cultured algae as a food supply

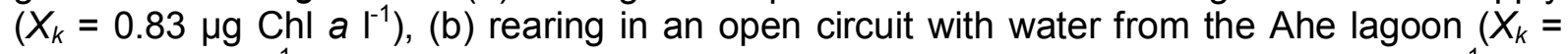

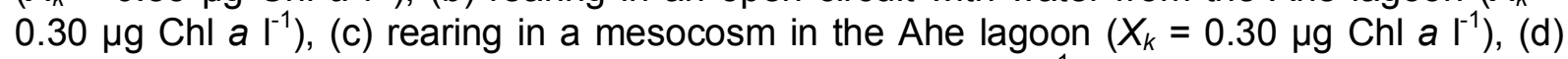
cohort identified in situ, in the Ahe lagoon $\left(X_{k}=0.15 \mu \mathrm{g} \mathrm{Chl} \mathrm{a}^{-1}\right)$.

Fig. 8 Variation of (a) the mean concentration of $\mathrm{Chl} a$ in vivo and (b) the mean temperature measured in the Ahe toll lagoon, depending on the geographic zone and the depth. Data measured in the Ahe lagoon during the 28-day study cruise in April-May 2007.

Fig. 9 Left: Profiles of simulated growth for the ensemble of strata according to larval age. Right: Estimation of size reached by larvae after 29 days of development according to geographic zone and depth $\left(X_{k}=0.15 \mu \mathrm{g} \mathrm{Chl} \mathrm{a}^{-1}\right)$.

Fig. 10 Left: evolution of the mean percentage ( \pm standard error) of $P$. margaritifera larvae reaching a minimum size of $230 \mu \mathrm{m}$, according to age. Right: estimation of the percentage of larvae having reached a minimum size of $230 \mu \mathrm{m}$ after 29 days of development, according to geographic zone and depth $\left(X_{k}=0.15 \mu \mathrm{g} \mathrm{Chl} \mathrm{a} \mathrm{^{-1 }}\right.$, standard deviation of the dispersion of size normalised $=15 \%$ of the mean length). 
Table 1. Equations describing the energy fluxes in the DEB model. $X$ corresponds to the food concentration ( $\mathrm{Chl} \mathrm{a,} \mathrm{g} \mathrm{I}^{-1}$ ) and $T$ to the water temperature $(\mathrm{K})$. See table 2 for the parameter description.

\begin{tabular}{|c|c|}
\hline Flux description & Equation \\
\hline Ingestion & $\dot{p}_{X}=\mu_{X} \cdot\left\{j_{X m}\right\} \cdot\left(\frac{X}{X+X}\right) \cdot V^{2 / 3} \cdot \dot{k}(T)$ \\
\hline Assimilation & $\dot{p}_{A}=\boldsymbol{\kappa}_{A} \cdot \dot{p}_{X}$ \\
\hline Catabolic flux & $\dot{\boldsymbol{p}}_{C}=\frac{E / V}{\left[E_{G}\right]+\kappa E / V}\left(\frac{\left[E_{G}\right] \cdot\left\{\dot{p}_{A m}\right\} \cdot V^{2 / 3}}{\left[E_{m}\right]}+\left[\dot{\boldsymbol{p}}_{M}\right] \cdot V\right)$ \\
\hline $\begin{array}{l}\text { Energy allocated to } \\
\text { structural biovolume }\end{array}$ & $\boldsymbol{p}_{G}=\kappa \cdot \boldsymbol{p}_{C}-\boldsymbol{p}_{M}$ \\
\hline $\begin{array}{l}\text { Maintenance of structural } \\
\text { biovolume } \\
\text { Energy allocated to } \\
\text { development }\end{array}$ & $\begin{array}{l}\dot{p}_{M}=\left[\dot{p}_{M}\right] \cdot V \cdot \dot{k}(T) \\
\dot{p}_{R}=(1-\kappa) \cdot \dot{p}_{C}-\dot{p}_{J}\end{array}$ \\
\hline $\begin{array}{l}\text { Maintenance of reproductive } \\
\text { structures }\end{array}$ & $\dot{p}_{j}=\min \left(V, V_{p}\right) \cdot\left[\dot{p}_{M}\right] \cdot\left(\frac{1-\kappa}{\kappa}\right) \cdot \dot{k}(T)$ \\
\hline Effect of the temperature & $\dot{k}(T)=\dot{k}_{1} \cdot \exp \left\{\frac{T_{A}}{T_{1}}-\frac{T_{A}}{T}\right\} \cdot\left(1+\exp \left\{\frac{T_{A L}}{T}-\frac{T_{A L}}{T_{L}}\right\}+\exp \left\{\frac{T_{A H}}{T_{H}}-\frac{T_{A H}}{T}\right\}\right)^{-1}$ \\
\hline $\begin{array}{l}\text { Conversion of } \begin{array}{r}\text { physical } \\
\text { length (L) into structural } \\
\text { volume (V) }\end{array} \\
\end{array}$ & $V=\left(\delta_{M} L\right)^{3}$ \\
\hline
\end{tabular}


Table 2. Parameters of the DEB model for the larval stage in $P$. margaritifera. The parameter $X_{k}$ was adjusted depending on the simulation: 0.83 for rearing with cultured algae, 0.3 for in situ rearing and 0.15 for the 'wild' cohort.

\begin{tabular}{|c|c|c|c|c|}
\hline Parameter & Symbol & Unit & Value & Ref. \\
\hline Arrhenius temperature & $\mathrm{T}_{\mathrm{A}}$ & $\mathrm{K}$ & 14000 & a \\
\hline Maximum surface-specific ingestion rate & $\left\{j_{x m}\right\}$ & $\mu m^{3} \mu m^{-2} d^{-1}$ & 37 & a \\
\hline Half-saturation coefficient & $x_{k}$ & $\mu g_{\text {Chl a }} \mu l^{-1}$ & $0.83 / 0.3 / 0.15$ & a \\
\hline Assimilation efficiency & $\kappa_{\mathrm{A}}$ & - & 0.75 & c \\
\hline Maximum surface-specific assimilation & $\left\{\dot{p}_{\text {am }}\right\}$ & $\mathrm{J} \mathrm{d}^{-1} \mathrm{~cm}^{-2}$ & 13 & a \\
\hline Volume-specific cost of growth & {$\left[E_{G}\right]$} & $\mathrm{J} \mathrm{cm}^{-3}$ & 1900 & c \\
\hline Volume-specific cost of maintenance & {$\left[\dot{p}_{M}\right]$} & $\mathrm{J} \mathrm{cm}^{-3} \mathrm{~d}^{-1}$ & 24 & c \\
\hline Maximum energy density & {$\left[E_{m}\right]$} & $\mathrm{J} \mathrm{cm}^{-3}$ & 2295 & $b$ \\
\hline Fraction of energy used for growth and & $\kappa$ & - & 0.45 & $\mathrm{~b}$ \\
\hline Shape coefficient & $\delta_{\mathrm{M}}$ & - & 0.64 & a \\
\hline Lower limit of the tolerance range & $\mathrm{T}_{\mathrm{L}}$ & K & 294 & a \\
\hline Upper limit of the tolerance range & $\mathrm{T}_{\mathrm{H}}$ & K & 303 & a \\
\hline Arrhenius temperature at the lower limit & $\mathrm{T}_{\mathrm{AL}}$ & $\mathrm{K}$ & 87600 & a \\
\hline Arrhenius temperature at the upper limit & $\mathrm{T}_{\mathrm{AH}}$ & K & 62200 & a \\
\hline Reference temperature & $\mathrm{T}_{1}$ & $\mathrm{~K}$ & 298 & a \\
\hline Energy content of food & $\mu_{\mathrm{x}}$ & $\mathrm{J} \mu \mathrm{m}^{-3}$ & $4.5 \times 10^{-9}$ & $\mathrm{~b}$ \\
\hline
\end{tabular}

${ }^{a}$ this study, ${ }^{b}$ Rico-Villa et al. (2009), ${ }^{c}$ van der Veer (2006) 


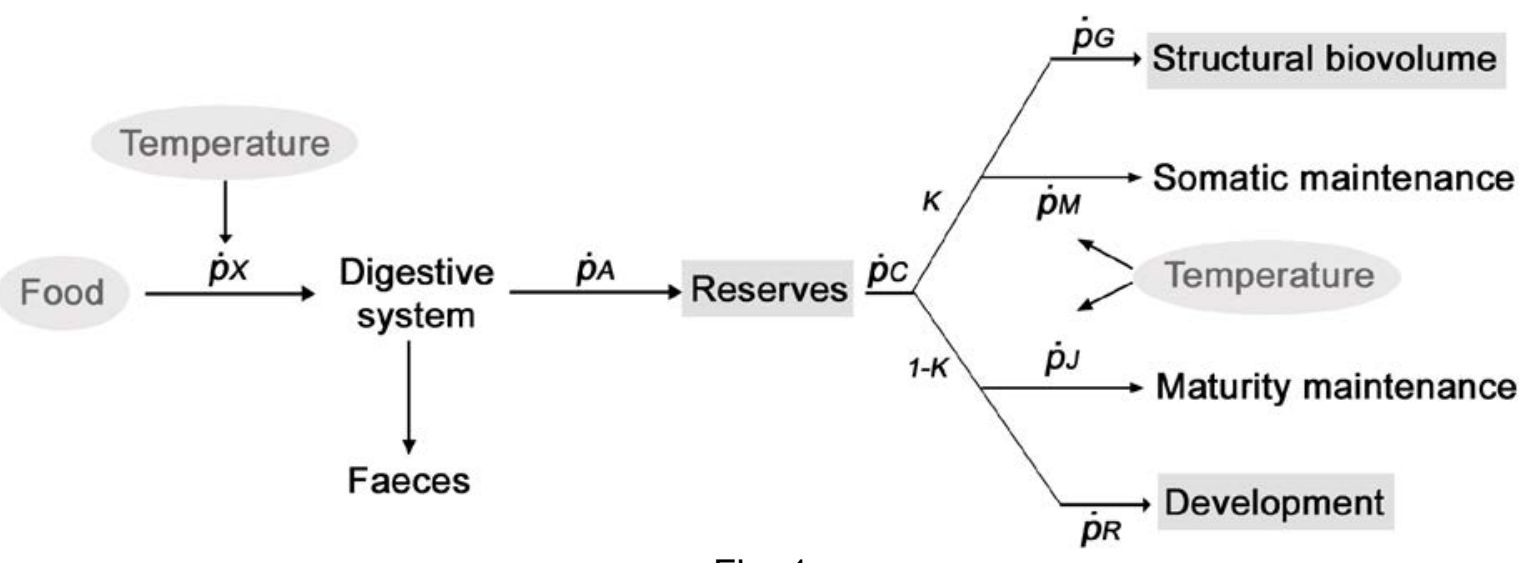

Fig. 1 

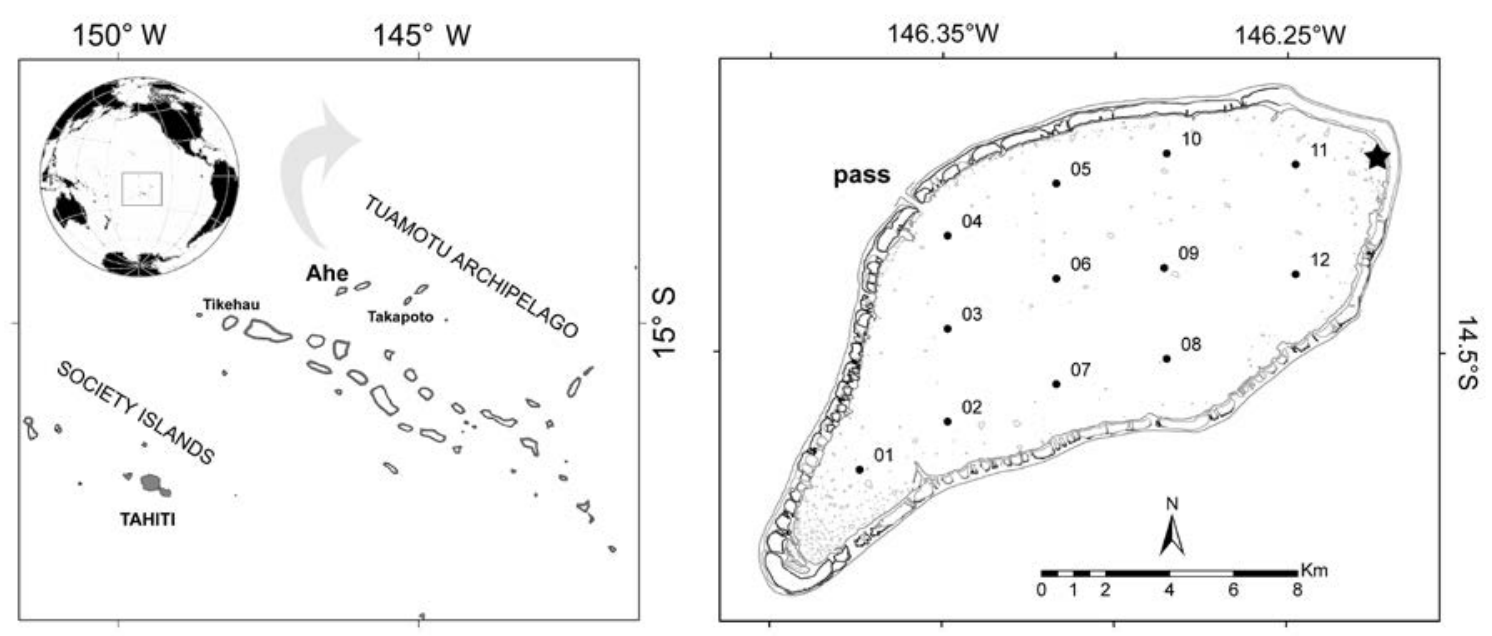

Fig. 2 


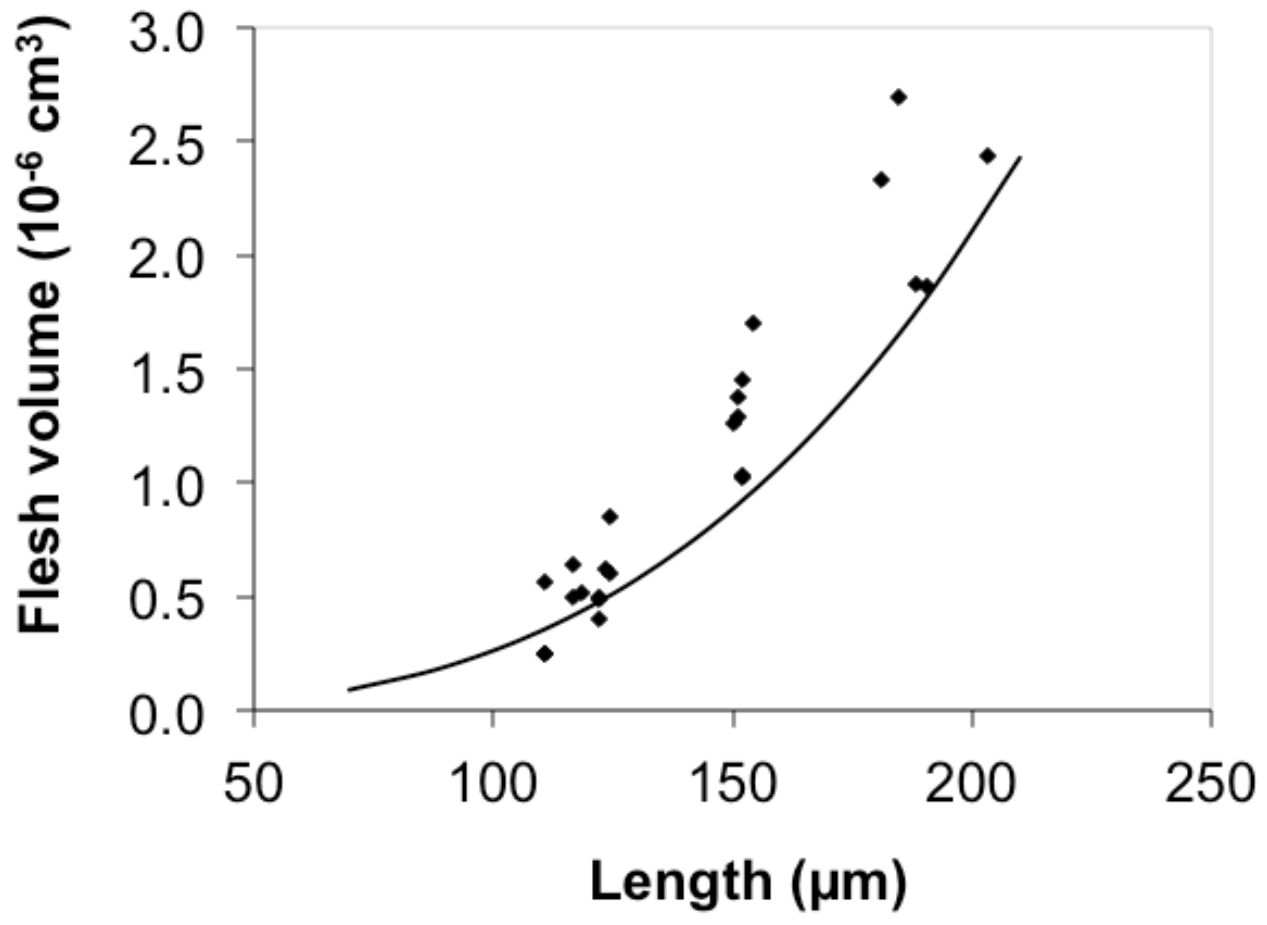

Fig. 3 


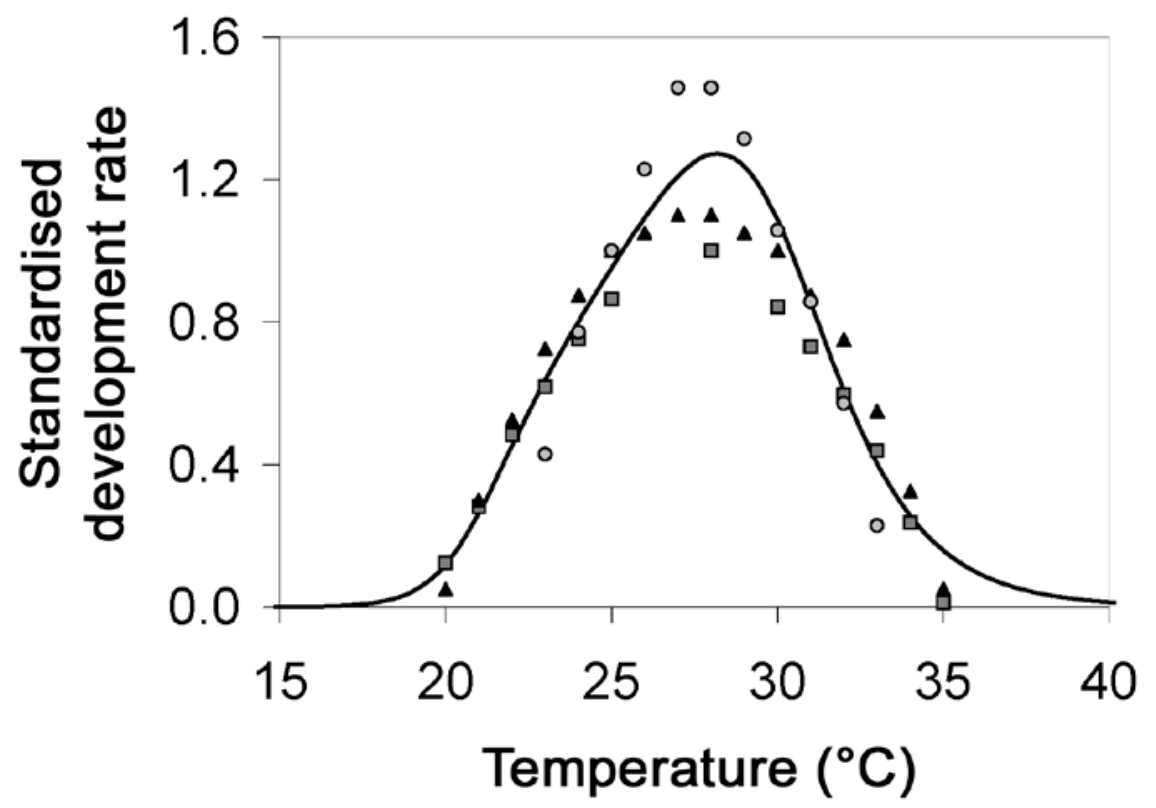

Fig. 4 


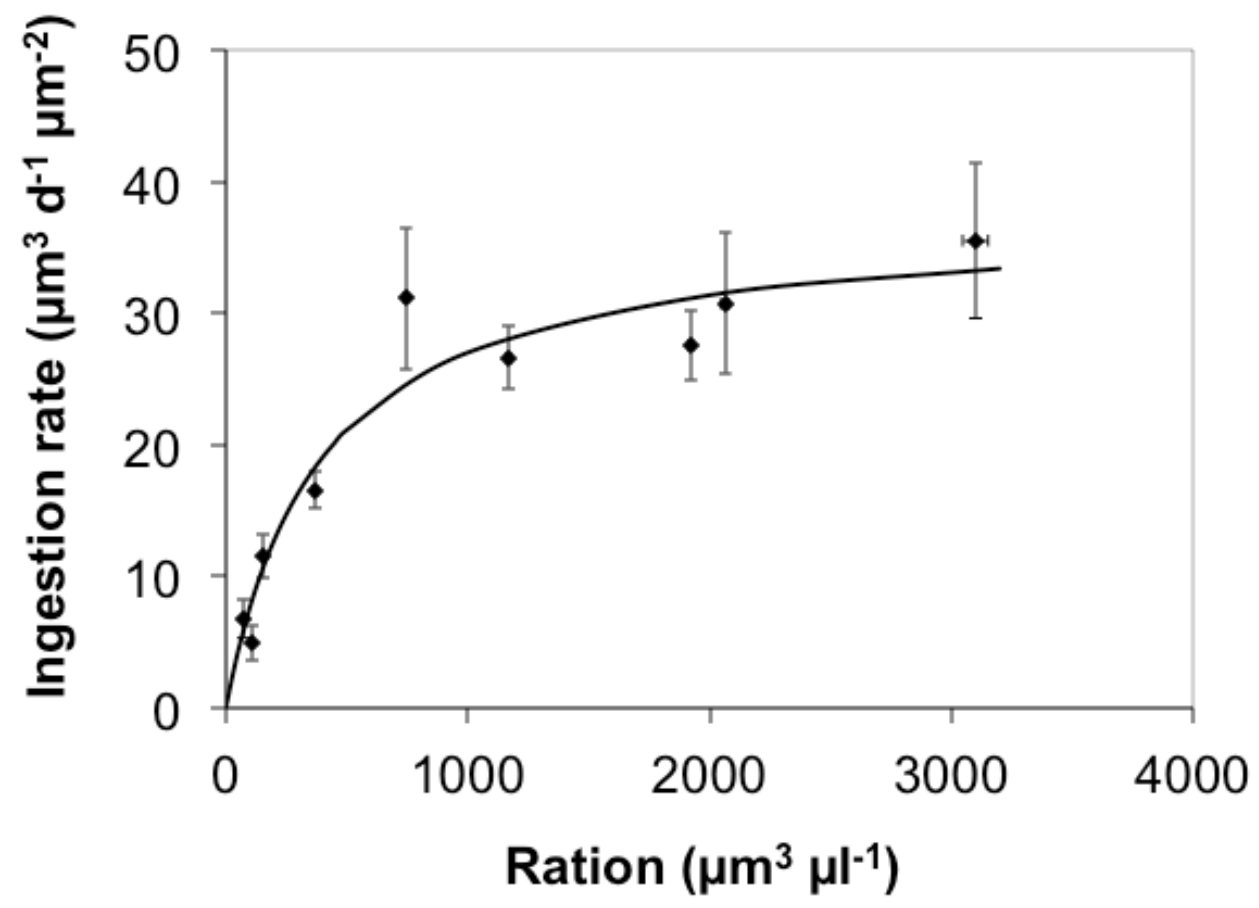

Fig. 5 
(a)

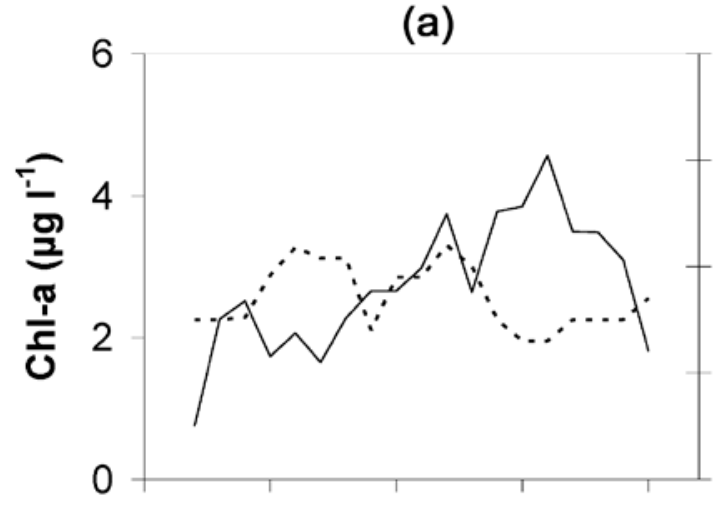

(c)

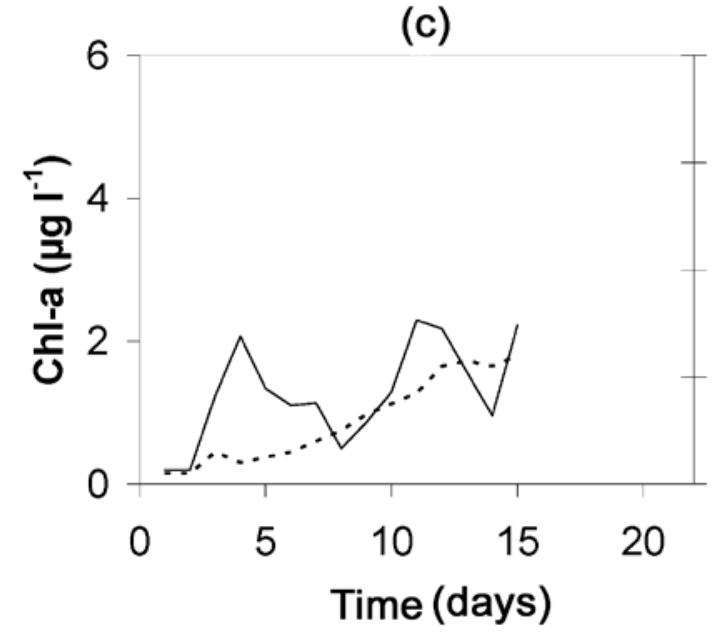

(b)

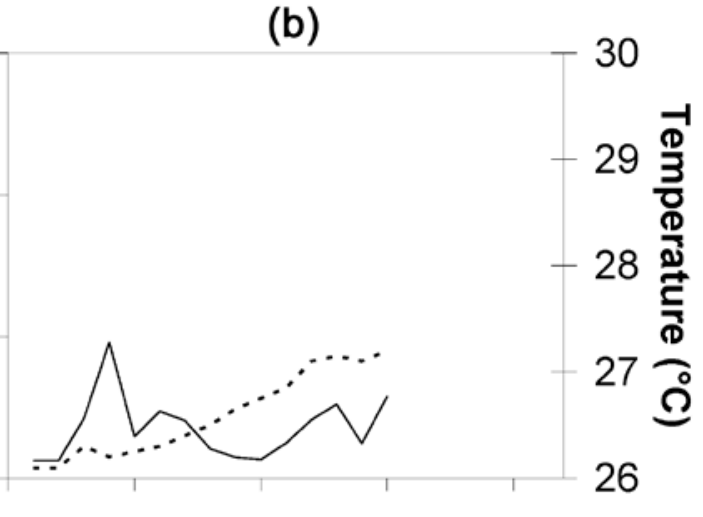

(d)

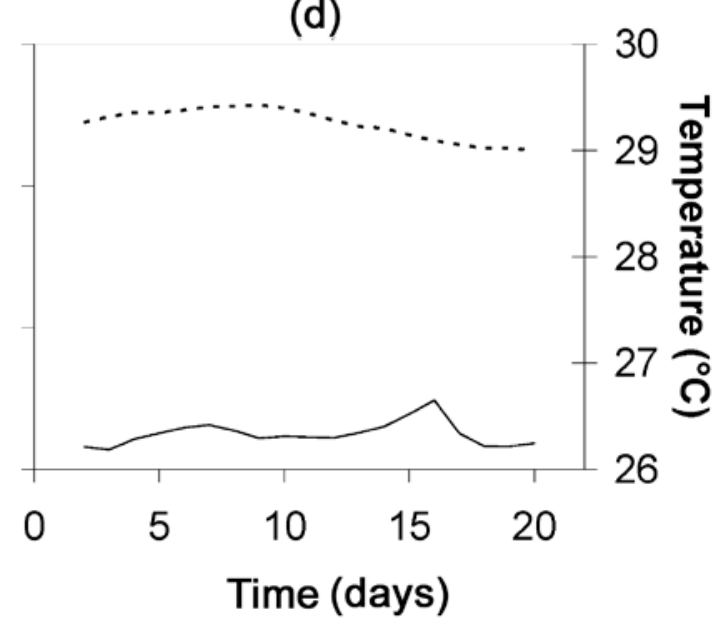

Fig. 6 
(a)

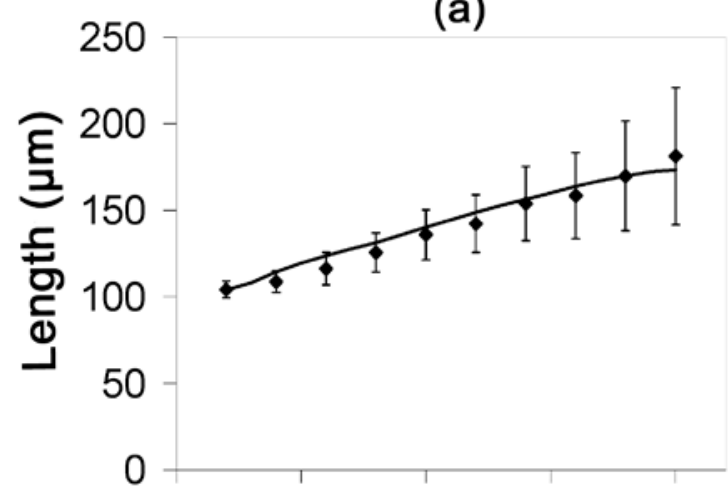

(c)

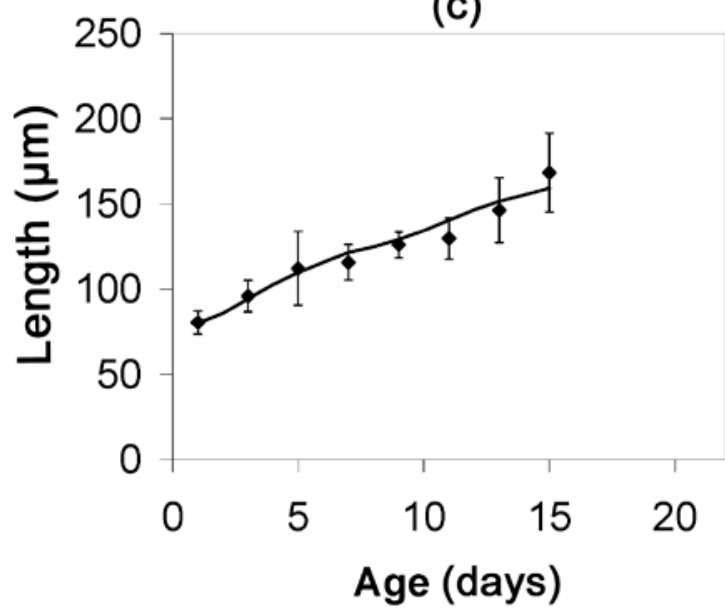

(b)

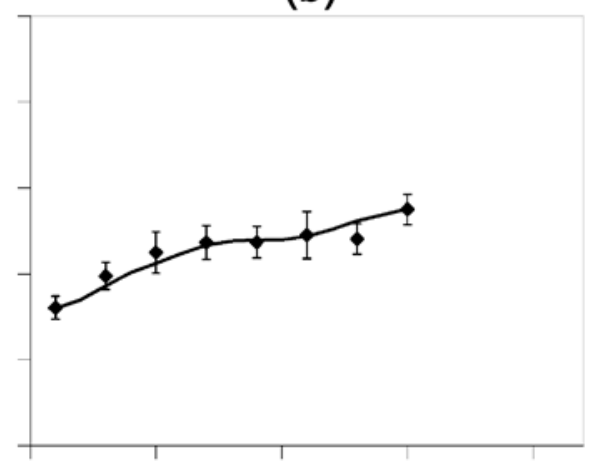

(d)

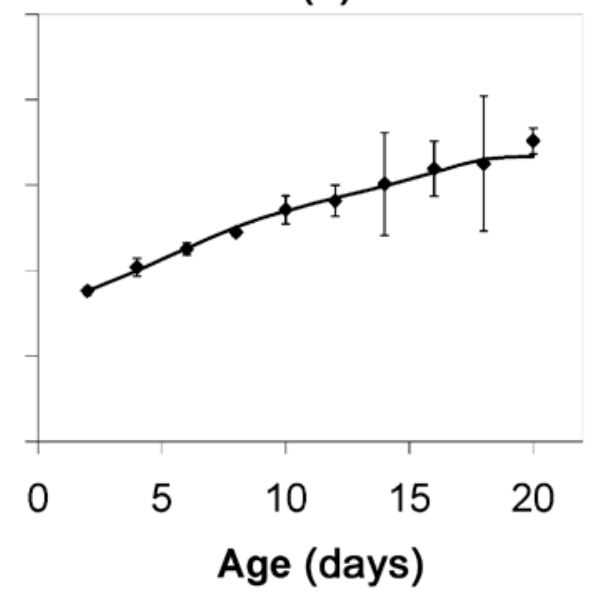

Fig. 7 
(a)

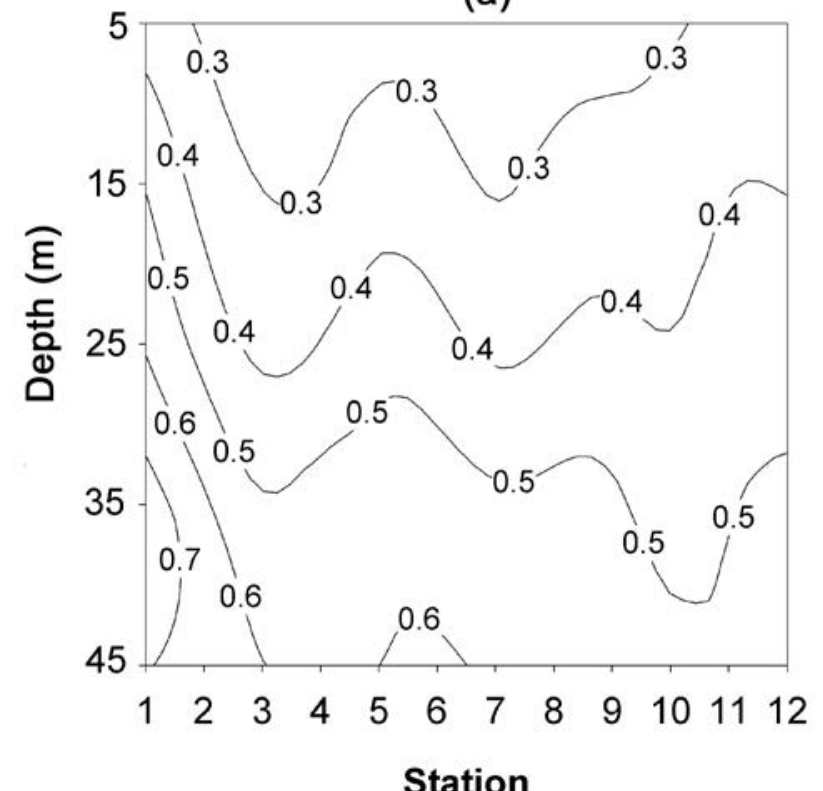

Station (b)

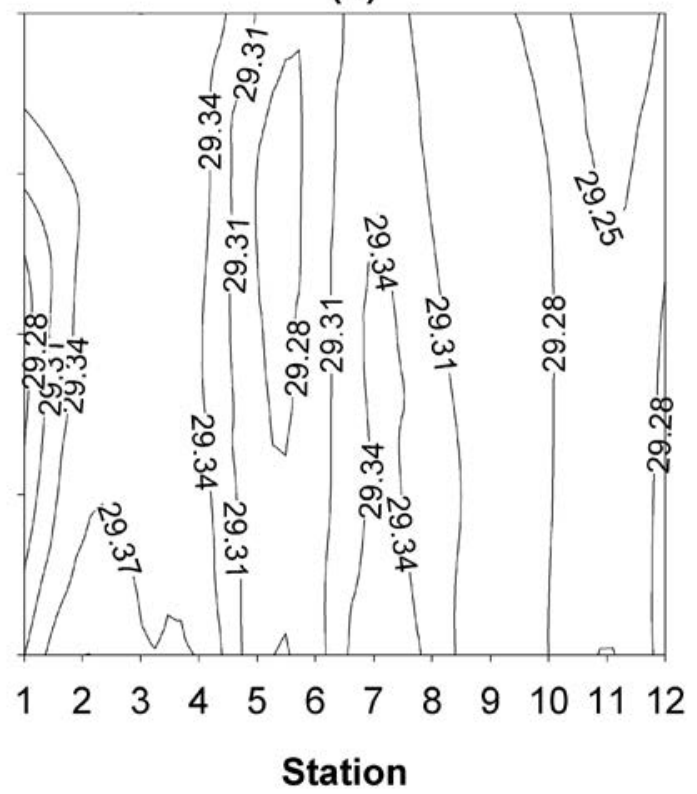

Fig. 8 

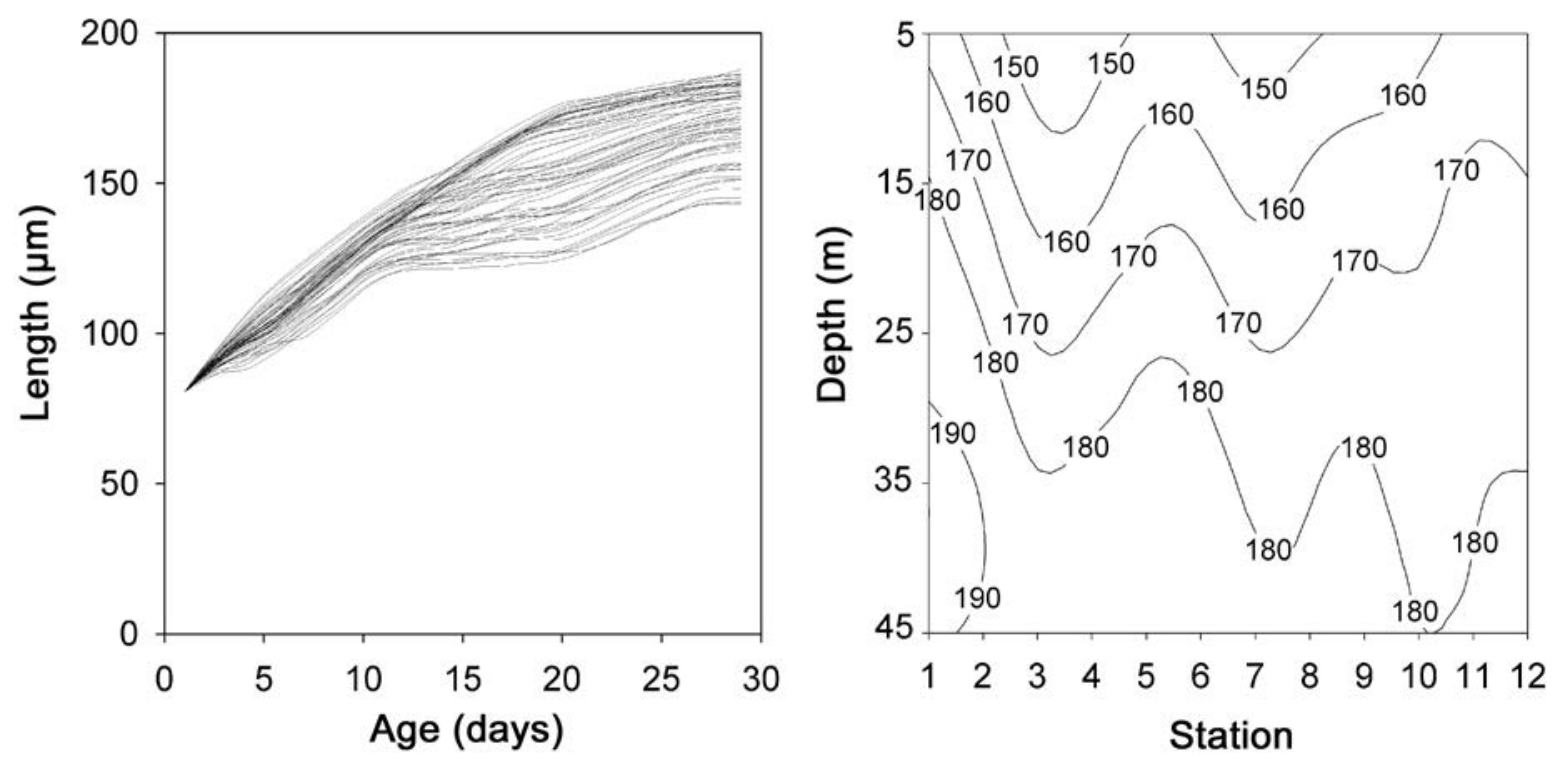

Fig. 9 

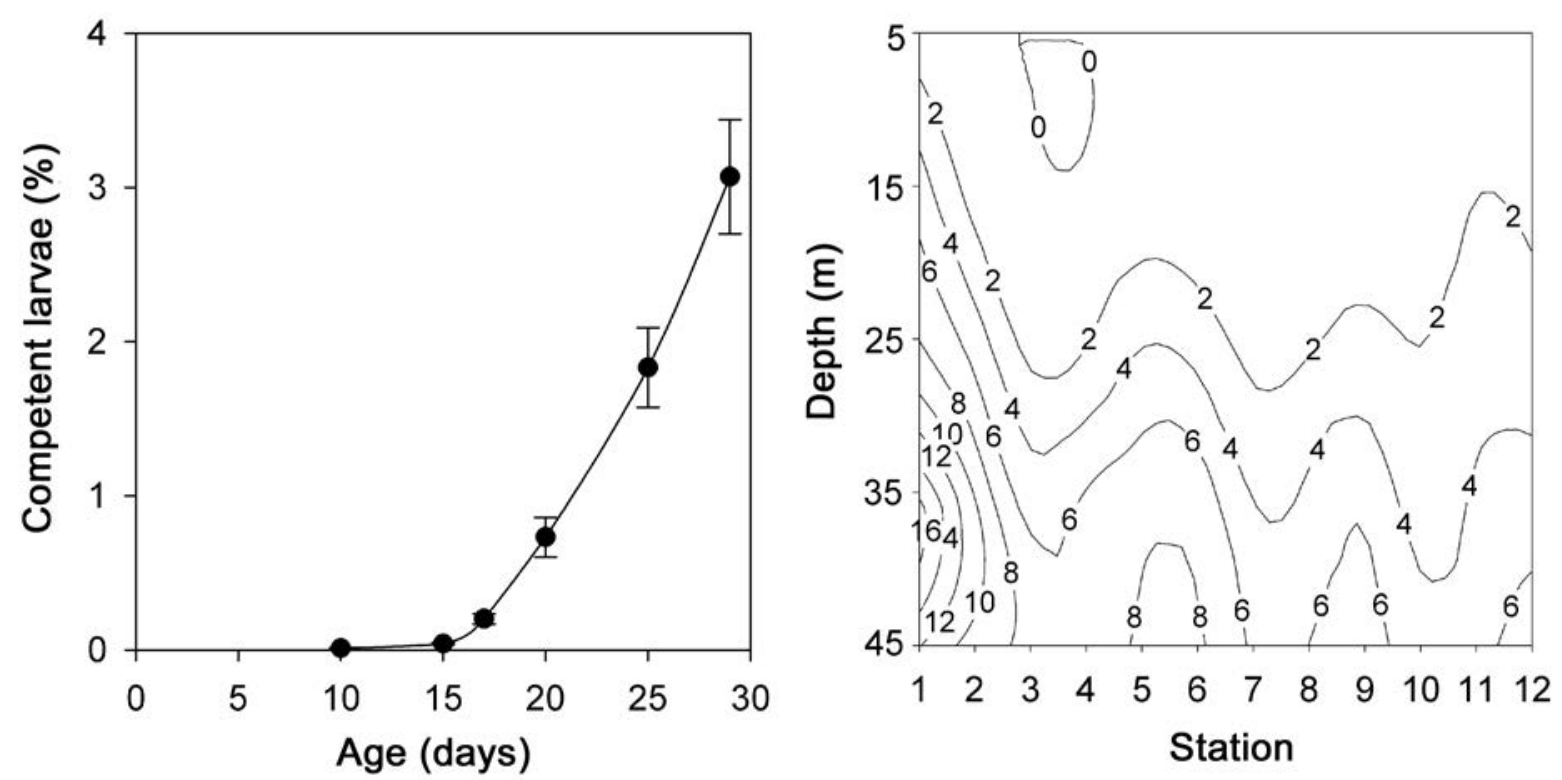

Fig. 10 